\title{
Determinants of Growth of Selected Renewable Energy Types within the Context of Sustainable Development
}

\begin{abstract}
The aim of this article is to identify the determinants affecting the growth of renewable energy source utilisation in rural areas in the context of sustainable development. The research covered the economic circumstances and changes in law relating to the RES (renewable energy sources) Act of 2018, which resulted from EU's energy policy ensuring favourable conditions for RES development and financial support for RE producers. Four sources of renewable energy relevant to rural farm and non-farm households are the focus of this article: wood biomass, biogas, biodiesel and solar energy. The discussion illustrates the role of rural households in the supply and use of RE consistent with the principle of sustainable development, describes rural residents' favourable attitudes towards financing RE projects from public funds, and the potential for creating local jobs in the RE sector, among others.
\end{abstract}

Keywords: sustainable development, renewable energy, subsidy, economic factors, legislative determinants, employment.

\section{Introduction}

In the history of social and economic thought and the history of development planning and programming, one would have difficulty finding a concept (or an idea) that is as widely accepted as the concept of sustainable development, both in various regions of the world as well as in different environments. It may well be claimed that principles of sustainable development have become the development paradigm,

Anna M. Klepacka, PhD, Warsaw University of Life Science (SGGW w Warszawie), Faculty of Production Engineering Department of Production Organization and Engineering, 164 Nowoursynowska St., 02-787 Warsaw, Poland, anna_klepacka@sggw.pl, ORCID: 0000-0002-2828-5429. 
therefore the paradigm of science (Wilkin 2013). ${ }^{1}$ Sustainable development is increasingly presented as a pathway to all that is good and desirable in society (Holden, Linnerud, Banister 2014). Its meaning relates to democracy, freedom and justice (Meadowcroft 2007). At the same time, humanity is faced with important societal challenges, such as: inadequate social, economic and institutional systems (Waas, Verbruggen, Wright 2010). Management of the natural resources makes it possible to address changing needs while preserving high quality of the environment and protecting its resources (Woś 1998).

With regard to rural areas, the concept of sustainable development assumes the priority of the natural environment when implementing objectives of strategic development and the vital relevance of the form of such activities (Żmija 2014). The depletion of natural resources and the progressive degradation of nature raise concerns from the sustainability point of view (Majewski 2008). Reconciliation of natural laws and the laws of economics requires adopting a direction in economic activity that is adjusted to the existing natural determinants, including needs and preferences of local societies and ecology standards (Urban 2003). Hence the implementation of sustainable development requires environmental awareness among residents of rural areas, who are the "environmental managers" as the beneficiaries of subsidies of agriculture environmental programmes (Krasowicz 2009). Subsidies from the EU funds (directed to the Common Agricultural Policy) have had a positive effect on the situation in agriculture (Poczta 2011). Production subsidies conducive to equalisation of incomes across farms engaged in agricultural production, which in turn contribute to the continuation of agricultural land use and promotes a sustainable management system (Kowalski, Rembisz 2005). The understanding of the sustainable development idea is closely connected with the state of the economy, which influences the welfare of society as a whole (Runowski 2001) and secures durability of the continuous existence of the economy (Runowski 2002). The awareness of threats due to exploitation of the natural environment along with a sense of responsibility towards future generations has become

1 The term (idea) "sustainable development" was coined in the WCED report (World Commission on Environment and Development) released in 1987 - "Our Common Future". "Sustainable development is possible at the current level of human civilization's development. The sustainable development means the development that meets the needs of the present without compromising the ability of future generations to meet their own needs". According to the report, it is a model of the economy with an appropriately and consciously shaped relationship between economic growth, concern for the natural environment and human health (WCED 1987). On the other hand, under the Constitution of the Republic of Poland adopted on 2 April 1997, "The Republic of Poland shall safeguard the independence and integrity of its territory and ensure the freedoms and rights of persons and citizens, the security of the citizens, safeguard the national heritage, and shall ensure the protection of the natural environment pursuant to the principle of sustainable development" (Chapter 1, art. 5). 
a challenge for politicians, entrepreneurs and individual citizens in the context of the "quality of life" (Majewski 2008). A common agreement on a single system of values consistent with the sustainable development principle is required on a global basis (Sztumski 2006). Achieving a consensus must involve rural residents, who account for about half of the population in the EU and exert substantial political and economic influence.

The application of the sustainable development principles, recognised in Poland's constitution, guides practical solutions. Access to energy is essential for economic development and the functioning of the modern society but energy generation poses a challenge to sustainable development. EU policies have embraced the principles of sustainable development and utilisation of renewable energy sources (RES). Assuring access to energy for rural residents is particularly important, because remote or low population-density areas are more vulnerable to energy supply disruptions, imposing costs on economic activity and lowering the quality of life. To reduce the risk of energy supply disruption, rural households, especially farm households, choose solid fossil fuels (for example coal), but burning these fuels pollutes the environment.

\section{Objective, materials and methods}

The aim of this article is an attempt to identify the determinants affecting the development of renewable energy sources in rural areas in the context of sustainable development. Demand for energy by rural residents exceeds that of urban residents in Poland, as shown in the annual per capita use of electricity and coal (GUS 2014), but rural households also have opportunities to utilise local sources of renewable energy, which may be less accessible in the urban environment. The use of wood biomass in the form of pellets used for heating is a primary example of such opportunities that have received little attention in the literature. Rural residents include individual farm and non-farm households, but also villages and whole rural communities, because some technology for generating energy from renewable sources exceeds an individual household's resources and requires substantial investment, for example, a local biogas plant or hydro-energy installation.

The article applies the descriptive method supplemented by the tabulation of key growth measures and attributes of renewable energy types. Data compiled from public sources are used to document the changes in renewable energy growth by source type. Unpublished data summaries from our own survey illustrate the rural residents' attitudes towards selected RES in Poland. Additionally, the article refers to relevant legal documents issued by the Republic of Poland and the European institutions pertaining to the renewable energy role. Finally, whenever possible, 
the article refers to important research publications pertaining to sustainable development principle, renewable energy and its use in rural areas.

\section{Determinants of the renewable energy sector essential for sustainable development}

"Sustainable rural development must be put at the top of the agenda of the European Union" (The Cork Declaration (European Commission 1996)). The Strategy for Responsible Development (SRD) adopted by Poland on 14 February 2017 is a superior strategy, which was Poland's response to the targets expressed in the 2030 Agenda. The model of development for Poland set in the strategy is coherent with the vision of the UN Agenda. The Agenda's seventh target is to ensure access to affordable, reliable, sustainable and modern energy for all. Issues concerning, among others, employment, food production and income are closely related to the energy in the sustainable development (SDG 2018) and the fundamental tenet of sustainable energy development (SED) is the efficient use of energy, human, financial and natural resources (Graczyk 2011). The setting of the detailed priorities of major importance had to be formulated for Poland (GUS 2018a) since the Agenda 2030 provides limited operational guidance (Hák, Janoušková, Moldan 2016).

The crucial element of RES development are laws and regulations. According to Andrzej Czerwiński, a member the lower chamber of the Polish parliament the Sejm - and the Chairman of the Parliamentary Team for the Energy Winter Package, the discussion on RES was fierce in 2009 (Stępiński 2018) and stressed the utmost importance of energy security and price stability. The investment in RE generation continued as the investors expected support from the government or the EU (through subsidies) to improve returns (Hryniewicz 2014). The RES Act has been changed four times in the past few years (2015-2017). Yet a transparent and stable regulatory environment is necessary to attract investment.

The unstable regulatory environment causes uncertainty for investors and limits the application of new technologies. The direct link between changes in the law and investment in the utilisation of various sources of renewable energy is illustrated by the auction mechanism, which was to replace the renewable energy support system operating until the end of June 2016, the "green certificates" (Magazyn Biomasa 2015). The transition from the green-certificate system to the auction system as the RE support mechanism compromised the system's transparency (Klepacka, Pawlik 2018). The first auction was delayed until December 2016 and the next did not take place until June 2017. The transition may have changed investors' attitudes, leading to the withdrawal from financing, among others, large, commercial solar 
installations while coinciding with the new period of cohesion fund transfer from the EU (2014-2020) and the termination of old and the delay of new renewable energy support programmes. For example, the year-to-year growth in solar energy generation capacity experienced a dramatic decline between 2016 and 2018 and that recorded in 2015 (Table 1). The results of the first two auctions showed interest in the construction of new photo-voltaic (PV) micro-installations with the capacity of less than $1 \mathrm{MW}$ and a total capacity of $400 \mathrm{MW}$ valued at $2 \mathrm{bn}$ PLN within the next two years (Wiśniewski, Oniszk-Popławska 2017).

The recovery observed in the installed solar-energy capacity in 2018 (Table 1) reflects the shift away from commercial installations to micro-installations owned by "prosumer"households (i.e., both buyers and sellers of energy). Rural households have been investing in thermal solar collectors for a number of years and, more recently, in the PV panels stimulating the local economy and benefiting financially from RE utilisation. The financial benefits include lower monthly energy bills, savings from the transportation lower coal volumes, and the disposal of less ash to local landfills.

The growth of the installed capacity stalled for all sources of RE in 2017 (Table 1). This is because the figures in Table 1 reflect not only the regulatory changes, but also the transition from the previous funding period (2007-2013) provided by the EU to the current period (2014-2020). The end of the previous period led to a decrease in available subsidies and grants at the time the new programme was not fully functioning. The most dramatic decline in the installed capacity of windmills captures the lower opportunities for subsidies and the change in regulations, which rendered many rural locations unsuitable for new wind farms. Few rural households directly benefited from wind farm installations. A number of local protests prevented the construction of windmills (Bednarek-Szczepańska 2016; Klepacka, Pieńczuk, Kamińska 2016; Łaguna 2015; Bielski 2002). The new RE law has extended the period of preparing site plans for new wind farm locations based on the earlier regulations (Krzyżanowska 2018) potentially causing additional confusion on the part of investors by creating loopholes and exceptions.

The emphasis on RE use has been increasing, reflecting the widespread recognition of the sustainable development principle. On 14 June 2018 the European Commission, the European Parliament and the Council of the EU agreed a new Renewable Energy Directive. The binding target of 32\% from renewable energy sources by 2030 with a periodic review of that goal and the possibility of upward revisions. The new target emphasises the role of prosumers, that is installation of facilities with the capacity of up to $25 \mathrm{~kW}$ (Ciepiela 2018). The low capacity of such installations still requires space, favouring rural households that commonly occupy larger plots. It is rural households in Poland that account for most residential use 


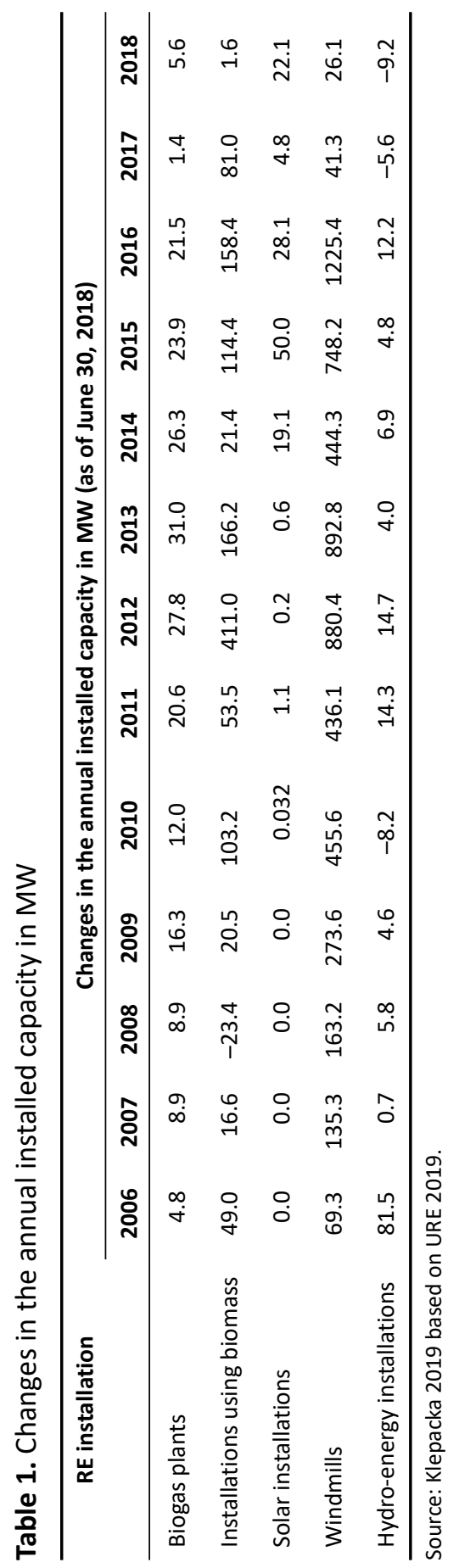


of fossil fuels and represent great potential for substituting their use by renewable energy sources, especially for heating, which is of major importance in household energy use.

The European Commission (2017) advocates RE use because of the beneficial spill-over effects and its societal importance, namely environmental and health benefits. Health benefits and their short-term and long-term effects lower the budgetary outlays on the healthcare system. The reduction of harmful GHG emissions and particulates is realised by use of heating systems such as solar collectors (Gaj, Pakuluk 2011), or burning wood waste in heating plants (Bioteam 2018).

\section{The effects of legal and economic determinants on the development of selected RES}

The aim of accessible energy for all as stated in the seventh goal of the UN 2030 Agenda reflects the ever-present and growing demand. Access in rural areas has been lagging behind urban areas, affecting the life quality and local economic development. Renewable energy offers access ability and local generation insulating rural areas from disruptions to energy supply, while at the same time contributing to sustainable development. In Poland, rural areas more frequently suffer from energy supply disruptions, yet rural households use more electricity than an average urban household. Rural households also heavily depend on coal for domestic heating. In 2012 , the average urban household used $2745.1 \mathrm{~kg}$ of coal, but the average household in rural areas used $3029 \mathrm{~kg}$ (GUS 2014). Although the use of coal in urban and rural households has declined, it is declining at a lower rate in rural areas, which continue to use more coal than urban households. Since the indicator of coal use in Poland is ten times higher than the EU average, rural households have a potentially important role in the reduction of fossil fuel use, advancing the idea of sustainable development.

The recent changes in law offer rural households the chance to become energy suppliers. A household installing solar-energy equipment becomes a prosumer and sells the PV electricity generated back to the grid. Not all types of RE are suitable for households to become prosumers, but several allow rural households to generate energy and lower the monthly energy bill, while at the same time cutting environmental pollution and contributing to the local economy in a way consistent with the principle of sustainable development.

There are several sources of renewable energy. This article covers four of them: wood biomass, biogas, biodiesel and solar energy. Each of these sources either permits a rural household to become involved, on the supply side or as a user of the "green" energy generated. For example, a rural household can use biomass 
or a solar heating panel to heat the living space, grow rapeseed for manufacturing biodiesel, or supply agricultural waste for biogas production.

\section{Wood biomass}

The new regulations change the definition of biomass. ${ }^{2}$ The key change in the law concerns the definition of energy generated from wood. Because of its quality and size as well as its physical and chemical properties, wood biomass has a lower technical and utility value, making its industrial use impossible (Article 2 Point 7a). ${ }^{3}$ The definition of biomass was expanded by adding "processed biomass, particularly in the form of briquettes, pellets, biochar and biocoal" (OdnawialneŹrodlaEnergii. pl. 2018; Magazyn Biomasa 2018). The market for pelleting and briquetting has been developing dynamically in Poland recently. Stoves fuelled by this type of material are gaining popularity due to relatively low heating costs in comparison with coal and natural gas (Magazyn Biomasa 2018) and the traditional use of wood (Trojanowska 2002). The pellet-burning stoves reduce carbon dioxide and particulate emissions significantly (Jędrak et al. 2017). These two issues are crucial in the pursuit of sustainable development. Since the primary users of coal are rural households, stoves burning wood pellets offer an economic alternative. Wood pellets are manufactured in rural areas, because those areas are also located close to forests, wood mills, and manufacturers of numerous wood products.

The supply of wood is likely to increase in the coming decades, enabling stable wood-pellet production because of the increase in the area of private forests, many owned by farms and rural households. This is a likely result of government environmental policy that has focused on increasing the forested area by permanently withdrawing poor quality arable land from production (class V and VI), previously

2 Biomass - solid or liquid material from plants and animals, which is the biodegradable portion of products, waste and residues from agriculture, forestry and related industries, as well as cereal grain that does not comply with equivalent minimum quality characteristics. Wood biomass is a waste resource that due to its quantitative, dimensional, physical and chemical properties has a reduced technical and utility value, making its industrial use impossible (Notice of the Marshall of the Sejm of 7 June 2018 on publication of the consolidated text of the Act on Renewable Sources of Energy).

3 These properties were described in the draft regulation of Minister of the Environment on detailed quantitative, dimensional, physical and chemical properties. The draft regulation introduces groups of raw materials complying with the definition of wood energy and they include: trunks or cut timber defined in $\$ 3$ and $\$ 4$ of the regulation, small timber $(M 1, M 2)$, wood in the form of tree-felling or improvement cutting waste including woodchip and bales), root wood, generated in forest production processes (sawdust, wood powder, chips, edgings, logs and briquettes and pellets resulting from their processing), wood products and elements as well as wood-based materials damaged or withdrawn from the market which are not contaminated with impregnates or protective coatings containing halogens or heavy metals (Olsztyńska 2017). 
owned by state farms, and a significant number of farmers who joined the forestation programme funded by government subsidies (Klepacka, Szmulewicz 2018). The subsidies for agricultural land reforestation have been provided from the cohesion funds allocated to the new EU member-countries in recent years.

Wood biomass use is consistent with the principles of sustainable development. Forests are perceived as an important element in the sustainable development strategy and the growth of forest areas remains the main target of the environmental policy (Klepacka, Florkowski, Bagińska 2017). Carbon sequestration is an important benefit of reforestation. For example, the forestation of 45,000 ha sequesters 0.5 million tonnes of carbon dioxide per year (Klepacka, Florkowski, RevoredoGiha 2017). Reducing deforestation and the expansion of the forest area mitigates climate change and enhances sustainable development (Ellison et al. 2017).

\section{Biogas}

In 2008, the Polish government adopted the "Secure Energy - Energy Agriculture" programme intended to achieve "a biogas plant in every municipality" by 2020. The programme implied the construction in all 2478 municipalities of over 25,000 biogas plants capable of generating approximately 3,000 MW of renewable energy (Michalski 2009). According to Piotr Gradziuk (2017). Pursuant to regulations adopted by the Council of Ministers in 2010, the programme would diversify the gas supply and fully satisfy the needs of rural gas recipients. Rural areas have been at a disadvantage in accessing gas from the grid, which even recently only covered about $18 \%$ of rural households (77\% in urban areas) (Kaliski et al. 2011).

The cost of biogas plants prevents their construction by individual rural households and the above-mentioned plan local governments to search for appropriate solutions. However, farm households could supply substrata needed to sustain the fermentation process generating biogas. The biogas plants can use various feedstocks, but the largest production potential is connected with the agriculture (Curkowski 2011/2012). Agriculture may supply substrata defined as "rural by-products and waste", including straw, manure, and unutilised silage. Since substrata also include food waste (Powałka et al. 2013), non-farm rural households can contribute to biogas production by separating food waste from other waste for local biogas plants. Mixing various substrata may improve the efficiency of the biogas production, while ensuring the production continuity regardless of the time of year (Florkowski, Us, Klepacka 2018). In that respect rural households have a direct advantage over urban households. The law defines the substrata very broadly, making space for local initiatives to secure various types of waste for biogas production (Dz.U. 2018 - Act of RES, article 2, item 2). 
Another important goal of the law on RES concerning biogas plant development is waste management, because substrata from rural households lower the waste disposed at landfills (Magazyn Biomasa 2018). As a result, biogas production in rural areas can contribute to renewable energy production and help in waste management, thus achieving two goals consistent with the sustainable development path, while improving the quality of rural residential life.

However, the biogas sector has not experienced an expansion in recent years as might be expected from the slogan "a biogas plant in every municipality" (Wieczerzak-Krusińska 2016). Tomasz Janas emphasised that it was the domestic and foreign investors' perception of the law (RES Act), which they see as extremely unstable, causing decision-makers to think twice before making an investment decision (Wieczerzak-Krusińska 2016). Despite the doubts, with EU support the biogas plants are contributing to achieving the renewable energy production target and the biogas plants operating in Lublin Voivodeship serve as examples (Florkowski, Us, Klepacka 2018).

Finally, farm and non-farm rural households can play an important role in increasing Poland's energy security. Taking into account the annual potential of biogas production of about $8 \mathrm{bn} \mathrm{m}^{3}$ of methane, even without the utilisation of crops such as corn, the sector's development could lead to the significant reduction in natural gas imports, or to the production of as much as 4,000 MW of stable, "green" electricity (Rynek Biogazu 2018).

\section{Biodiesel}

Biodiesel is the most important biofuel type produced and used in the EU (Sorda, Banse, Kemfert 2010), with rapeseed as the primary crop for its production. The EU is the largest producer of rapeseed (33\% of world production) (Ploplis 2017). Beside France and Germany, Poland is the leader in biodiesel production in the EU (Klepacka, Florkowski, Revoredo-Giha 2019). Its production is promoted not only within the framework of the EU agricultural policy, but also in climatechange and energy policies.

Demand for biodiesel in Poland directly affects farm households as rapeseed suppliers press the oil for further processing into the fuel. The global biodiesel trade has been affected by the EU policy targets, which have been reflected in significant imports of the palm oil for biodiesel production, among others. In 2014, the EU was the second largest palm-oil importer, and as much as $45 \%$ of the world's palm-oil production was used in transport (as biodiesel) (Klepacka, Florkowski, Revoredo-Giha 2019). The European Commission aims to eliminate palm oil as a biodiesel feedstock after 2021, because of its harmful environmental effects 
and incompatibility with the demanded target of the change in land use (ILUC) (Ciepiela 2018). These changes have created additional demand for rapeseed, which, as a result, have contributed to the increase in the rapeseed area sown from $4 \%$ to 9\% in total crop area in Poland in the period 2013-2015 (Klepacka, Florkowski, Revoredo-Giha 2019). The rapeseed harvest was estimated at $2.7 \mathrm{~m}$ tonnes in 2017, roughly 44.2\% more than in 2011 (Klepacka, Mączyńska 2018a).

The interest in rapeseed production farms results mainly from its more competitive prices compared to cereals. Competitive rapeseed prices encourage farmers to grow it in regions where one would rarely find its traditional producers, for example in Podlaskie. Yet it is in these areas where agriculture is of relatively greater importance. The highest profitability indicator was recorded in Wielkopolskie Voivodeship (213.2\%), with the lowest in Łodzkie Voivodeship (134.5\%); but the profitability indicator with and without subsidies was recorded at more than $100 \%$ in all voivodeships. The highest production cost was in the Pomorskie Voivodeship (PLN127.7 per $1 \mathrm{dt}$ ) and the lowest in Wielkopolskie Voivodeship (PLN 80.71 per 1 dt) (Klepacka, Mączyńska 2018b).

Demand for biodiesel offers opportunities for farmers to contribute to RE utilisation, while at the same time protecting soil fertility by replacing grains with rapeseed and improving crop rotation. As a result, farm households assume an active role in supplying the oilseed crop benefiting from sales, and become users of biodiesel in fuel used in agricultural equipment, while advancing the idea of sustainable development through the protection of soil fertility associated with the improved crop rotation.

\section{Solar energy}

Solar energy has become quite popular in Poland in recent years. Małgorzata Trojanowska (2002) estimated that nearly one in twelve farmers surveyed was interested in purchasing solar heating panels. Widespread public acceptance of this type of renewable energy has been repeatedly confirmed in other countries and in Poland (Xueliang, Zuo, Ma 2011; Us, Florkowski, Klepacka 2014; Klepacka, Buska 2015).

Rural households benefited from subsidies for the purchase and installation of solar panels before such programmes were created for urban residents. Targeting rural areas was justified because three million single-family houses (about $55 \%$ of all such homes in Poland in 2011) are located in rural areas (REF). The growth of single-family houses is also faster in rural than urban areas. Additionally, there are about five million other structures in rural areas (REF) including cow stalls, chicken coops, grain barns, machine sheds, multifunctional improvements, etc., 
each with a roof for possible placement of solar panels and direct contribution to the EU 2020 renewable energy mandate.

Rural households have been the primary investors in solar heating panels for about a decade. The utilisation of solar energy illustrates the crucial importance of financing in efforts to increase renewable energy utilisation. Per capita income in rural households is commonly lower than in urban households and lower incomes represent a real constraint in investing in clean energy (GUS 2018b). The first transfer of cohesion funds in the 2007-2013 period allowed funding of subsidies for the purchase and installation of solar heating panels. Numerous farm and nonfarm households benefited throughout the country. Examples include households in Wisznica municipality in Lubelskie Voivodeship (Siedlecka, Grąszko 2016). In Mazowieckie Voivodeship the four-municipality project provided an $85 \%$ subsidy (70\% from EU funds and 15\% from local government) to rural households, who invested the remaining 15\% (Klepacka, Florkowski, Meng 2018). Additionally, a programme sponsored by the Swiss government also provided grants for the installation of solar heating panels in selected areas of Poland.

Rural households directly benefited from the investment in solar heating panels by improving their access to hot water, primarily between April and October as dictated by the seasonal patterns of solar radiation intensity. The measurable financial benefits to rural households are associated with lower energy costs by reducing the use of coal for hot water. For example, the project in the Mazowieckie Voivodeship contributed to the decrease in greenhouse gas emissions, in particular carbon dioxide, of 232,000 tonnes a year by using solar collectors and heat pumps (Siudek, Klepacka 2018).

Rural areas also benefited from investment in commercial PV installations. Because the installation of solar panels demands a sizable area, commercial installations have been located in rural areas on land of that could not generate competitive returns through agricultural use. An example of a commercial PV installation is a plant in Jadowniki in the Małopolskie Voivodeship (Klepacka, Pawlik 2018).

The availability of the next generation of solar equipment, the photovoltaic panels, was not matched by the investment in rural areas, because of the lack of regulations on households' sale of electricity back to the grid. It was not until the passing of new law (RES Act, June 26, 2016), which created a new category of producers of electricity from renewable energy, the prosumers, that provided incentive for PV panel investment. The 2018 RES Act changed the range of power for micro-installations from $40 \mathrm{~kW}$ to $50 \mathrm{~kW}$, and for small installations from $200 \mathrm{~kW}$ to $500 \mathrm{~kW}$. Overall, the new law discourages investment in large commercial $\mathrm{PV}$ plants because it changes the return on investment and demonstrates a shift 
in policy away from the commercial installation to micro-installations (Klepacka, Pawlik 2018).

The use of solar energy also stresses the key role of regulations, or specifically, demonstrates how changes in law alter the return on investment and discourage commercial investors from the construction of new PV power plants in favour of micro-installations. Such shifts in policy have implications for local job creation. Although commercial solar installation may generate fewer jobs, they are permanently tied to the location. Micro-installations mostly involve jobs associated with the purchase and mounting of the equipment, but maintaining such jobs requires a firm to search for investors at new locations, possibly with only a transitory effect on local job creation. A future study may compare whether the benefits of rural household investment in micro-installations in solar energy outweigh the investment in commercial solar installation in terms of their effects on local job markets.

\section{Selected renewable energy sources and economic factors, sustainable development features and public attitudes}

Table 2 shows selected RES features to illustrate the essence of individual sources in the context of sustainable development with the emphasis on rural households' role in generating and using energy from renewable sources. The features listed represent the key economic measures, including the unit price of energy generated from selected renewable sources, a descriptor reflecting the reliability of energy supply from each renewable source, and a measure of efficiency. Employment is a macroeconomic indicator, measured in the number of full-time jobs generated by each renewable energy subsector. Another measure demonstrates the effect of each type of renewable energy source consistent with the principle of sustainable development: greenhouse gas emission per kWh of energy generated. Indicators of all renewable sources are compared to the standard fuel used by rural households - coal. Additionally, recognising the importance of household preferences regarding the use of a specific type of energy, Table 2 shows public attitudes towards each energy source.

Price and economic indicators. The energy price per unit is dependent on the location and the business environment (infrastructure). Prices fluctuate widely for each renewable energy source (Table 2). On average prices, the highest unit price of energy is photovoltaic, which is six times that of coal. Biomass also exhibits a wide range in the unit price of energy. A large portion of biomass is designated for processing into liquid and solid biofuels. In 2013, the average unit price of biodiesel was $0.097 \$ / \mathrm{kWh}(0.036-0.10)$, biogas $0.072 \$ / \mathrm{kWh}(0.032-0.126)$, and biomethane $0.0766 \$ / \mathrm{kWh}(0.053-0.1414)$ (Naumann, Oehmichen, Zeymer 2014). The cost 
of producing biofuels is related to the regulations and the availability of the raw materials. The lowest average energy prices are for wind farms, hydroelectric plants and coal.

Table 2. Comparison of unit prices, other economic measures, environmental benefits, and public attitudes with regard to selected renewable energy sources

\begin{tabular}{|c|c|c|c|c|c|c|}
\hline \multirow[t]{2}{*}{ Factors } & \multicolumn{6}{|c|}{ Selected energy sources } \\
\hline & $\begin{array}{l}\text { Biomass } \\
\text { (solid and } \\
\text { liquid } \\
\text { biofuels) }\end{array}$ & $\begin{array}{l}\text { Solar } \\
\text { energy } \\
\text { PV cells }\end{array}$ & Wind & Hydropower & Geothermal & Coal \\
\hline $\begin{array}{l}\text { Unit price } \\
\text { (\$/kWh) }\end{array}$ & $\begin{array}{c}0.05- \\
0.15^{*} \\
0.068 * *\end{array}$ & $\begin{array}{c}0.05-2 * \\
0.24 * *\end{array}$ & $\begin{array}{c}0.04-0.2^{*} \\
0.051^{* *}\end{array}$ & $\begin{array}{c}0.01-0.2^{*} \\
0.051^{* *}\end{array}$ & $\begin{array}{c}0.02-0.1^{*} \\
0.066^{* *}\end{array}$ & $\begin{array}{c}0.08- \\
0.09^{*} \\
0.048^{* *}\end{array}$ \\
\hline Media stability & Stable & $\begin{array}{l}\text { Unstable, } \\
\text { cyclical }\end{array}$ & $\begin{array}{l}\text { Unstable, } \\
\text { not cyclical }\end{array}$ & Stable & Stable & Stable \\
\hline $\begin{array}{l}\text { Overall } \\
\text { efficiency (\%) }\end{array}$ & $16-43$ & $4-22$ & $24-54$ & $>90$ & $10-20$ & $32-45$ \\
\hline $\begin{array}{l}\text { Average } \\
\text { greenhouse gas } \\
\text { emission } \\
\left(\mathrm{CO}_{2} \mathrm{e} / \mathrm{kWh}\right)\end{array}$ & 80 & 100 & 25 & 41 & 120 & 1000 \\
\hline 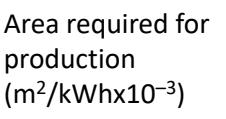 & 12.6 & $0.16-0.46$ & $1.8-5.5$ & 4.1 & $1.8-7.4$ & 0.48 \\
\hline \multicolumn{7}{|l|}{$\begin{array}{l}\text { Social } \\
\text { perception (\%) }\end{array}$} \\
\hline Acceptance & 31.2 & 95.7 & 91.1 & 70.6 & $x$ & 23.8 \\
\hline Disapproval & 66.0 & 1.8 & 6.4 & 27.0 & $\mathrm{x}$ & 74.8 \\
\hline No opinion & 2.8 & 2.5 & 2.5 & 2.5 & $x$ & 1.4 \\
\hline $\begin{array}{l}\text { Employment } \\
\text { (in millions) }\end{array}$ & 3.06 & 3.37 & 1.15 & 1.51 & 0.09 & $\mathrm{x}$ \\
\hline
\end{tabular}

* Change in the cost of generating a unit of energy over time depends on the production method.

** Average value for 2010-2017 (global, average price of electricity from renewable energy technologies on an industrial scale).

Source: Own study based on: IRENA (2018a). Renewable Energy and Jobs Annual Review 2018 and IRENA (2018b). Renewable Power Generation Costs in 2017 and Evans, Strezov, Evans 2010.

Energy supply stability is of immense importance when making use of renewable energy sources (Table 2) and is a priority for rural households that suffer 
from energy supply disruption and high coal prices. The energy sourced from hydropower, geothermal and biomass can be regarded as stable. This results from continued access to the supply of feedstock or energy carrier. In particular, biomass energy in the form of wood pellets is an attractive renewable alternative to coal. The recently implemented programme subsidising the replacement of fossil-fuelusing household stoves is especially attractive to rural households because wood pellet manufacturers are often located near forested areas, which are also near rural settlements. Stability of supply, proximity, and lower ash volumes are attributes that increase the acceptance of this type of renewable energy by rural households.

The energy supply from wind farms is considered extremely uncertain, not only due to lack of stability of weather patterns, but also due to lack of clear cycles, which makes electricity production harder to predict. The energy from PV cells may also seem unstable (a satisfactory level of sunshine falls within the period from April to September in Poland) and this cyclical instability weakens its practical use.

An element reflecting the level of RE development sources is employment in each subsector. The highest level of employment was noted in the case of solar energy, the PV-cell subsector and biomass use, which confirm the development opportunities for the future use of all these sources.

Environmental effects. Renewable energy sources, which are regarded as low or zero-emission sources (when viewed as a whole), may be a source of substantial greenhouse gas emissions. For example, PV cells do not emit greenhouse gas when in operation, but their production requires carbon-intensive technologies. Nevertheless, solar energy generation causes ten times lower GHG emissions than coal, and even slightly less than geothermal energy (Table 2).

One of the least appreciated parameters is the surface area efficiency defined as surface area occupied by the energy source in relation to the energy produced (Table 2). The largest area is occupied by biomass energy production, in contrast to PV cells, whose unit surface area is one hundred times lower than biomass. Wood biomass production uses by far the largest area, because it originates from forested land. However, forests provide other benefits, such as carbon sequestration and producing a local cooling effect through shade (Wolff et al. 2018). Since the promotion of increasing the forested area is also linked to climate policy, areas supplying wood biomass will always be extensive. In Poland, the production of wood biomass is in synergy with the national programme of expanding the forest area and consistent with the implementation of a sustainable development path. The production of biofuels (bioethanol and biodiesel) also involves large land areas and the re-allocation of land from growing food and feed crops to biofuel crops. In Poland, such areas became available as a result of the dramatic changes in crop mix and a decrease of area planted in potatoes and sugar beet. Indeed, expanding 
the area of rapeseed improves soil fertility. Biogas production uses various substrata and its effect on land is limited, since some substrata are agricultural waste that is already supplied by productive land. Solar heating panels or PV cells installed by rural households use roofs or walls of the residential homes or farm buildings and generally do not require additional land. Commercial PV installations are few, and those that have been built use land in rural areas that was marginal when used for farming.

Household preferences measured by attitudes. Public support for renewable energy development is of great importance. The level of public support changes along with the perception of possible risks. In this context, PV cells have the best reputation. This results from direct observations of the nature of the work of this type of installation and the absence of carbonisation accorded to them. Wind farms are considered a clean energy source, but the impact on landscape and the alleged negative health impact lowers their public acceptability. An interesting phenomenon is the low level of public acceptance of biomass production. This mainly results from the high level of emissions observed by the public in comparison with PV cells for example.

Attitudes of rural residents in the Mazowieckie Voivodeship. A survey of residents of four municipalities in the Mazowieckie Voivodeship and participants in the solar energy purchase and installation project provides additional insights into the attitudes towards selected RES. The summary of the survey involving 123 rural households has not been published and reveals that, when asked if they would pay more for energy from renewable energy than for energy from conventional sources, the proportion of those responding in the affirmative varied. In the case of biogas, $37 \%$ of respondents indicated they were willing to pay more for energy from this type of RE than for energy from conventional sources. The proportion of respondents willing to pay increased to $41 \%$ in the case of biofuels, but $53 \%$ were willing to pay for solar energy. Overall, the results show surprisingly positive attitudes towards RE, and the proportion of rural respondents willing to pay more for RE is quite surprising given that the four-municipality area has incomes below the national average.

Not surprisingly, the same survey revealed that the respondents overwhelmingly supported the government programme backing the development of RE. In the case of biogas, $80 \%$ of respondents favoured such a programme, for biofuels it was $82 \%$, but for solar energy nearly $97 \%$ had a favourable view of government support for this form of RE.

Employment in Poland. An element reflecting the level of RE development sources is employment, especially in rural areas which in Poland have a higher unemployment rate than urban areas. Poland is fourth among the EU countries 
in the number of employees in the RE sector (Globenergia.pl 2018). However, in Poland the largest number of jobs, 30,000 (8th in the world), is associated with biofuels and includes all jobs involved in the production, transport, and processing of substrata (Globenergia.pl 2018). As such, farmers growing rapeseed are taken into consideration, but these are not new jobs, since farmers were growing other crops before they began supplying bio-refineries. The number of jobs associated with biomass can be expected to grow because there is increasing support for this form of RE in EU countries. Poland and five other EU countries account for half of all jobs in this sector in the EU-28 (Globenergia.pl 2018). Solar energy jobs were associated with heating-panel investment, but recent changes in the law and subsidy programmes will cause more jobs to be associated with PV installations, resembling the global trends.

\section{Conclusions}

Energy based on renewable sources is the most important element of social and economic growth in the context of sustainable development. The discord between legislative changes and economic incentives has slowed the sector development in Poland. Thus the legislative authorities play a key role in guaranteeing stable social and economic growth, gradually changing energy generation from conventional energy sources in favour renewables. In this context, the RES Act is a crucial legal document, whose purpose is to ensure favourable conditions for the development of the RES sector and guarantee the financial support system for RE producers. The four RES considered in this article - wood biomass, biogas, biodiesel and solar energy - demonstrate their significant role in the RE sector development and the opportunities they provide for rural households to benefit from becoming suppliers and users of green energy. The following conclusions can be drawn, among others:

1. Wood biomass production can be expected to be increasingly important in reducing the dependence of rural households on non-renewable fossil fuels, because of opportunities to increase wood-pellet production and installation of pellet-burning stoves. Forestation of relatively low quality agricultural land contributes to carbon sequestration and mitigates progressive climate change, while creating a local supply of wood for local pellet manufacturers. The environmental benefits increase because of the planned configuration of plantings (location, size, distribution of tree species, tree density). An additional benefit of private forest expansion is the "cooling" effect, which can influence local health and well-being. Moreover, changes in the land market regulations may result in the "return" of rural 
land heirs, who can see forestation as a long-term investment, and, by foresting low quality land, may contribute to the growth of the renewable energy sector.

2. Biogas plants can make use of various agricultural raw materials and waste. This results mainly from the well-developed food production sector as well as the large amount of agricultural land. Thanks to the variety of the substrates and waste (including food) accessible in rural areas, biogas production is possible regardless of the season. Taking into account the production potential of biogas on a national scale only in rural areas, the sector's development may lead to the emergence of stable "green" energy in the electro-energy network meeting rural communities' energy demands. However, the typical biogas plant requires resources unlikely to be available to individual rural households, stressing the crucial role of local governments as the primary investors. Support from the EU cohesion funds is helpful. It should be noted that, despite the existing national biogas production programme, the growth of the sector has been slow.

3. Biodiesel, the most important biofuel produced and used in the EU, creates additional demand for rapeseed from Polish farmers. It offers rural areas the chance to become major suppliers of feedstock for biodiesel, while improving crop rotation and benefiting soil productivity, an essential element of sustainable development.

4. Solar energy is well accepted by the public and rural residents in Poland. Its use limits the adverse effects of using coal for domestic heating in rural households, associated with air pollution, greenhouse-gas emissions and disposal of ash. However, as in the case of other RES, solar energy use depends heavily on legislative action and the financial support for investors in solar micro-installations. The conditions have been created for the accelerated growth of PV investment with the recent regulatory changes and new funds from the EU cohesion funds.

The realities of economic and natural conditions in rural Poland suggest that not all RES are of equal importance. Additionally, various types of RE offer different opportunities for farm and non-farm households. Further promoting rural household investment in RES requires a combination of transparent, stable regulations and financial support to fully exploit the already expressed acceptance of green energy. Rural households, which account for nearly half of all Polish households, can make a major contribution to energy generation and use, advancing the goals of sustainable development. 


\section{Bibliography}

Bednarek-Szczepańska M. (2016). Energetyka wiatrowa jako przedmiot konfliktów lokalizacyjnych w Polsce. Polityka Energetyczna, 19 (1), 53-72.

Bielski W. (2002). Energetyka wiatrowa: Różne interesy, różne spojrzenia. Wiadomości Elektrotechniczne, 70 (4), 129-131.

Bioteam (2018). Projekt: Optymalizacja zrównoważonych systemów przetwarzania i dostaw bioenergii na konkurencyjnych rynkach w Europie. Część 5.1. Strategiczne decyzje dla bioenergii z wykorzystaniem narzędzia do optymalizacji mikro-ekonomicznej - Polska. www.sustainable-biomass.eu [accessed: 31.12.2018].

Ciepiela D. (2018). Uwaga! Uzgodniono nowe cele OZE na rok 2030. https://energetyka. wnp.pl/uwaga-uzgodniono-nowe-cele-oze-na-rok-2030,325063_1_0_0.html [accessed: 31.10.2018].

Curkowski A. (2011/2012). Rynek biogazu rolniczego: Stan obecny i perspektywy rozwoju sektora. Energetyka Cieplna i Zawodowa, 12 (1), 1-6.

Dz.U. (2018). Dz.U. 1276. Ustawa z dnia 7 czerwca 2018 r. o zmianie ustawy o odnawialnych źródłach energii oraz niektórych innych ustaw (art. 2, punkt 2; art. 2 punkt 7a; art. 39), http://www.dziennikustaw.gov.pl/DU/2018/1276 [accessed: 31.10.2018].

Ellison D., Morris C.E., Locatelli B., Sheil D., Cohen J., Murdiyarso D., Gutierrez V., Noordwijk M.v., Creed I.F., Pokorny J., Gaveau D., Spracklen D.V., Tobella A.B., Ilstedt U., Teuling A.J., Gebrehiwot S.G., Sands D.C., Muys B., Verbist B., Springgay E., Sugandi Y., Sullivan C.A. (2017). Trees, forests and water: Cool insights for a hot world. Global Environmental Change, 43, 51-61.

European Commission (1996). The Cork Declaration "A Living Countryside". Report of the European Conference on Rural Development in Cork, Ireland, $7^{\text {th }}$ to $9^{\text {th }}$ November, 1996.

European Commission (2017). The EU Environmental Implementation Review (EIR) package. Communication: The EU Environmental Implementation Review: Common challenges and how to Combine Efforts to Deliver Better Results. Annex: Guidance to member states: suggested actions on better environmental Implementation. 28 Country reports (SWDs) http://ec.europa.eu/environment/eir/index_en.htm [accessed: 14.03.2019].

Evans A., Strezov V., Evans T. (2010). Comparing the Sustainability Parameters of Renewable, Nuclear and Fossil Fuel Electricity Generation Technologies. Congress Paper. World Energy Council for Sustainable Energy, $21^{\text {st }}$ World Energy Congress $12^{\text {th }}$ to $16^{\text {th }}$ September 2010, Montreal, Canada.

Florkowski W.J., Us A., Klepacka A.M. (2018). Food waste in rural households support for local biogas production in Lubelskie Voivodship (Poland). Resources, Conservation and Recycling, 136, 46-52.

Gaj K., Pakuluk A. (2011). Efekty ekonomiczne zastosowania kolektorów słonecznych w domu jednorodzinnym. Polska Energetyka Słoneczna, 2-4, 49-53.

Globenergia.pl. (2018). Ponad $10 \mathrm{mln}$ miejsc pracy w branży OZE. https://globenergia.pl/ ponad-10-mln-osob-miejsc-pracy-w-branzy-oze/ [accessed: 05.02.2019]. 
Graczyk A.M. (2011). Narzędzia wspomagania zrównoważonego rozwoju energetycznego w gminie Prusice. Barometr Regionalny, 4 (26), 53-58.

Gradziuk P. (2017). Potencjał i prognozy wykorzystania biogazu rolniczego w Polsce. Roczniki Naukowe Stowarzyszenia Ekonomistów Rolnictwa i Agrobiznesu, 19 (3), 64-70. GUS (2014). Zużycie energii w gospodarstwach domowych w 2012 roku. Warszawa: Główny Urząd Statystyczny. https://stat.gov.pl/files/gfx/portalinformacyjny/pl/defaultaktualnosci/5485/2/3/1/zuzycie_energii_w_gospodarstwach_domowych_w_2013_r..pdf [accessed: 31.12.2018].

GUS (2018a). Agenda na rzecz Zrównoważonego Rozwoju 2030. Warszawa: Główny Urząd Statystyczny. https://sdg.stat.gov.pl [accessed: 31.10.2018].

GUS (2018b). Sytuacja gospodarstw domowych w 2017 r. w świetle wyników badania budżetów gospodarstw domowych. Warszawa: Główny Urząd Statystyczny https://stat.gov. pl/files/gfx/portalinformacyjny/pl/defaultaktualnosci/5486/3/17/1/sytuacja_gospodarstw_domowych_w_2017.pdf [accessed: 06.02.2018].

Hák T., Janoušková S., Moldan B. (2016). Sustainable development goals: A need for relevant indicators. Ecological Indicators, 60, 565-573.

Holden E., Linnerud K., Banister D. (2014). Sustainable development: Our Common Future revisited. Global Environmental Change, 26, 130-139.

Hryniewicz M. (2014). Analiza opłacalności wybranej technologii produkcji energii elektrycznej z biomasy z użyciem ogniw paliwowych. Problemy Inżynierii Rolniczej, 4 (86), $71-80$.

IRENA (2018a). Renewable Energy and Jobs Annual Review 2018. Abu Dhabi: International Renewable Energy Agency. http://irena.org/publications/2018/May/Renewable-Energyand-Jobs-Annual-Review-2018 [accessed: 31.10.2018].

IRENA (2018b). Renewable Power Generation Costs in 2017. Abu Dhabi: International Renewable Energy Agency. https://www.irena.org/-/media/Files/IRENA/Agency/Publication/2018/Jan/IRENA_2017_Power_Costs_2018.pdf [accessed: 31.10.2018].

Jędrak J., Konduracka E., Badyda A.J., Dąbrowiecki P. (2017). Wpływ zanieczyszczeń powietrza na zdrowie. Kraków: Polskie Towarzystwo Medycyny Środowiskowej, Wojskowy Instytut Medyczny, Polska Federacja Stowarzyszeń Chorych na Astmę, Alergię i POChP.

Kaliski M., Sikora S., Szurlej A., Janusz P. (2011). Wykorzystanie gazu ziemnego w gospodarstwach domowych w Polsce. Nafta-Gaz, 67 (2), 125-134.

Klepacka A.M. (2019). Significance of renewable energy sources in sustainable development. Annals of the Polish Association of Agricultural and Agribusiness Economists, 21 (1), $55-64$.

Klepacka A.M., Buska, A. (2015). Ocena znajomości wykorzystania energii słonecznej oraz dofinansowania $\mathrm{z}$ budżetu rządowego rozwoju odnawialnych źródeł energii w opinii mieszkańców wybranych gmin powiatu włodawskiego. Wieś Jutra, 3, 9-12.

Klepacka A.M., Florkowski W.J., Bagińska M. (2017). Zmiany w użytkowaniu ziemi: Ilustracja skutków wsparcia programów regionalnych w zwiększaniu udziału lasów na przykładzie województwa podlaskiego. Roczniki Naukowe Stowarzyszenia Ekonomistów Rolnictwa i Agrobiznesu, 19 (5), 106-112. 
Klepacka A.M., Florkowski W.J., Revoredo-Giha C. (2017). Farmers and their groves: Will cost inefficiency lead to land use change? Land Use Policy, 61, 329-338.

Klepacka A.M., Florkowski W.J., Meng T. (2018). Clean, accessible, and cost-saving: Reasons for rural household investment in solar panels in Poland. Resources, Conservation and Recycling, 139, 338-350.

Klepacka A.M., Florkowski W.J., Revoredo-Giha C. (2019). The expansion and changing cropping pattern of rapeseed production and biodiesel manufacturing in Poland. Renewable Energy, 133, 155-165.

Klepacka A.M., Mączyńska J. (2018a). Wpływ unijnych dyrektyw w zakresie wykorzystania biopaliw na rozwój obszarów wiejskich w Polsce. Roczniki Naukowe Stowarzyszenia Ekonomistów Rolnictwa i Agrobiznesu, 20 (2), 84-90.

Klepacka A.M., Mączyńska J. (2018b). Zróżnicowanie poziomu kosztów produkcji surowców rolnych wykorzystywanych do wytworzenia bioetanolu i estrów metylowych w ujęciu przestrzennym. Roczniki Naukowe Stowarzyszenia Ekonomistów Rolnictwa i Agrobiznesu, 20 (4), 78-84.

Klepacka A.M., Pawlik K. (2018). Return on investment in PV power plants under changing support regimes (schemes). Problems of Agricultural Economics, 356 (3), 168-191.

Klepacka A.M., Pieńczuk E., Kamińska N. (2016). The use of solar energy in the opinion of county employees in Mazowieckie Voivodship. $15^{\text {th }}$ International Scientific Days "Challenges and Prospects for Innovation between 2014-2020". Gyöngyös: Károly Róbert College. Electronic document: 869-876.

Klepacka A.M., Szmulewicz P. (2018). Sustainable development and forestation rate in selected voivodships in Poland. Ekonomia i Środowisko, 1 (64), 132-143.

Kowalski A., Rembisz W. (2005). Rynek rolny i interwencjonizm a efektywność $i$ sprawiedliwość społeczna. Warszawa: Instytut Ekonomiki Rolnictwa i Gospodarki Żywnościowej - Państwowy Instytut Badawczy.

Krasowicz S. (2009). Możliwości rozwoju różnych systemów rolniczych w Polsce. Roczniki Nauk Rolniczych, Seria G, 96 (4), 110-121.

Krzyżanowska A. (2018). Wiatraki bliżej domów jednorodzinnych: Projekt ustawy odległościowej. Rzeczpospolita. https://www.rp.pl/Nieruchomosci/305249988-Wiatraki-blizejdomow-jednorodzinnych---projekt-ustawy-odleglosciowej.htm [accessed: 01.02.2019].

Łaguna D. (2015). Finansowe skutki lokalizacji elektrowni wiatrowych w przestrzeni rolniczej. Ekonomia i Środowisko, 3 (54), 67-80.

Magazyn Biomasa (2015). Uruchomienie systemu aukcyjnego prawdopodobnie odroczone. https://magazynbiomasa.pl/uruchomienie-systemu-aukcyjnego-prawdopodobnie-odroczone/ [accessed: 31.10.2018].

Magazyn Biomasa (2018). Rząd przyjął nowelizacji ustawy o OZE. http://magazynbiomasa. pl/rzad-przyjal-nowelizacje-ustawy-o-oze/ [accessed: 31.10.2018].

Majewski E. (2008). Trwały rozwój i trwałe rolnictwo: Teoria a praktyka gospodarstw rolniczych. Warszawa: Wydawnictwo Szkoły Głównej Gospodarstwa Wiejskiego.

Meadowcroft J. (2007). Who is in charge here? Governance for sustainable development in a complex world. Journal of Environmental Policy \& Planning, 9 (3-4), 299-314. 
Michalski T. (2009). Biogazownia w każdej gminie: Czy wystarczy surowca? https://www. wnp.pl/wiadomosci/biogazownia-w-kazdej-gminie-czy-wystarczy-surowca,-5425.html [accessed: 31.10.2018].

Naumann K., Oehmichen K., Zeymer M. (2014). Monitoring Biokraftstoffsektor. DBFZ Report, 11 (2). Leipzig: Deutsches Biomasseforschungszentrum.

OdnawialnezrodlaEnergii.pl (2018). Nowelizacja ustawy OZE wprowadza wiele zmian $w$ obszarze energetyki biomasowej. http://odnawialnezrodlaenergii.pl/ustawa-o-odnawialnych-zrodlach-energii/item/3787-nowelizacja-ustawy-oze-wprowadza-wiele-zmian-w-obszarze-energetyki-biomasowej [accessed: 31.10.2018].

Olsztyńska I. (2017). Drewno na cele energetyczne, czyli drewno energetyczne. http://magazynbiomasa.pl/drewno-cele-energetyczne-czyli-drewno-energetyczne/ [accessed: 31.10.2018].

Ploplis E. (2017). Rynek rzepaku: Spodziewana dobra koniunktura! https://www.agrofakt. $\mathrm{pl} /$ prognozy-cen-rzepaku-dobra-koniunktura-2017/ [accessed: 31.10.2018].

Poczta W. (2011). Uwarunkowania społeczne i ekonomiczne rozwoju rolnictwa w Polsce. W: Agronomia w zrównoważonym rozwoju współczesnego rolnictwa. Materiały IV Konferencji Naukowej PTA, 5-7 września 2011, SGGW. Warszawa: Szkoła Główna Gospodarstwa Wiejskiego.

Powałka A.M., Klepacka A.M., Golisz E., Skudlarski J. (2013). Aktualna sytuacja sektora biogazu rolniczego w Polsce na tle Unii Europejskiej. Zeszyty Naukowe Szkoty Głównej Gospodarstwa Wiejskiego w Warszawie. Problemy Rolnictwa Światowego, 13 (28), 203-212.

Rozporządzenie Ministerstwa Środowiska w sprawie szczegółowych cech jakościowo-wymiarowych i fizyko-chemicznych drewna energetycznego ( $\$ 3$ i $\$ 4)$. Projekt rozporządzenia w sprawie drewna energetycznego. https://www.drewno.pl/artykuly/10714,projekt-rozporzadzenia-w-sprawie-drewna-energetycznego.html [accessed: 31.10.2018].

Runowski H. (2001). Zrównoważony rozwój gospodarstw i przedsiębiorstw rolniczych. Roczniki Naukowe Stowarzyszenia Ekonomistów Rolnictwa i Agrobiznesu, 2 (1), 94-102.

Runowski H. (2002). Rozwój zrównoważony rolnictwa i gospodarstw rolniczych: Wieś i rolnictwo - perspektywy rozwoju. Warszawa: Instytutu Ekonomiki Rolnictwa i Gospodarki Żywnościowej - Państwowy Instytut Badawczy, Instytut Rozwoju Wsi i Rolnictwa PAN, Szkoła Główna Handlowa - Katedra Agrobiznesu.

Rynek Biogazu. (2018). Potencjał rozwoju sektora biogazu w Polsce. http://rynekbiogazu. pl/2018/03/21/potencjal-rozwoju-sektora-biogazu-w-polsce/ [accessed: 31.10.2018].

Siedlecka A., Grąszko B. (2016). Odnawialne źródła energii jako narzędzie oddziaływania na jakość życia gospodarstw domowych. Roczniki Naukowe Stowarzyszenia Ekonomistów Rolnictwa i Agrobiznesu, 18 (2), 237-242.

Siudek A., Klepacka A.M. (2018). Impact of the RES micro-installations in single-family house on carbon dioxide emission reduction. Roczniki Naukowe Stowarzyszenia Ekonomistów Rolnictwa i Agrobiznesu, 20 (5), 193-199.

Sorda G., Banse M., Kemfert C. (2010). An overview of biofuel policies across the world. Energy Policy, 38 (11), 6977-6988. 
Stępiński P. (2018). Niekończąca się nowelizacja OZE (relacja). http://biznesalert.pl/niekonczaca-sie-nowela-oze-relacja/ [accessed: 31.10.2018].

Sustainable Development Goals (SDG) (2018). Affordable and Clean Energy, Goal 7. https:// www.un.org/sustainabledevelopment/energy [accessed: 31.10.2018].

Sztumski W. (2006). Idea zrównoważonego rozwoju a możliwości jej urzeczywistnienia. Problemy Ekorozwoju, 1 (2), 73-76.

Trojanowska M. (2002). Analiza popytu na energię elektryczną odbiorców wiejskich. Wiadomości Elektrotechniczne, 70 (10-11), 403-405.

Urban S. (2003). Rola ziemi w rolnictwie zrównoważonym a aktualne jej zasoby w Polsce. Acta Agraria et Silvestria. Series Agraria (Sekcja Ekonomiczna), 40, 25-36.

URE (2019). Moc zainstalowana (MW). Warszawa: Urząd Regulacji Energetyki. https:// www.ure.gov.pl/pl/oze/potencjal-krajowy-oze/5753,Moc-zainstalowana-MW.html [accessed: 15.01.2019].

Us A., Florkowski W.J., Klepacka A.M. (2014). Knowledge of Renewable Energy Sources (RES) and the tendency to install solar panels for households. Economic and Regional Studies, 7 (4), 86-98.

Waas T., Verbruggen A., Wright T. (2010). University research for sustainable development: Definition and characteristics explored. Journal of Cleaner Production, 18 (7), 629-636.

WCED (1987). Our Common Future. World Commission on Environment and Development. Oxford: Oxford University Press. http://www.un-documents.net/our-common-future.pdf [accessed: 31.10.2018].

Wieczerzak-Krusińska A. (2016). Nie będzie biogazowni w każdej gminie. https://energia.rp.pl/nowa-energia/8863-nie-bedzie-biogazowni-w-kazdej-gminie [accessed: 31.10.2018].

Wilkin J. (2013). Cele i zasady koordynacji polityk wspierających zrównoważony rozwój obszarów wiejskich. W: K. Heffner (red.). Rozwój obszarów wiejskich w Polsce a polityka spójności Unii Europejskiej: Stare problemy i nowe wyzwania (s. 25-36). Studia KPZK PAN, 154. Warszawa: Komitet Przestrzennego Zagospodarowania Kraju Polskiej Akademii Nauk.

Wiśniewski G., Oniszk-Popławska A. (2017). Krajowy Plan Rozwoju Mikroinstalacji Odnawialnych Źródeł Energii do 2030 roku. Warszawa: Instytut Energii Odnawialnej.

Wolff N.H., Yuta J.M., Meijaard E., Wells J.A., Edward T., Game E.T. (2018). Impacts of tropical deforestation on local temperature and human well-being perceptions. Global Environmental Change, 52, 181-189.

Woś A. (1998). Rolnictwo zrównoważone. W: A. Woś (red.). Encyklopedia agrobiznesu (s. 735). Warszawa: Fundacja Innowacja.

Xueliang Y., Zuo J., Ma C. (2011). Social acceptance of solar energy technologies in China: End users' perspective. Energy Policy, 39 (3), 1031-1036.

Żmija D. (2014). Zrównoważony rozwój rolnictwa i obszarów wiejskich w Polsce. W: A. Barteczek, A. Rączaszek (red.). Polityka gospodarcza w okresie transformacji i kryzysu (s. 149-158). Studia Ekonomiczne. Zeszyty Naukowe Wydziałowe Uniwersytetu Ekonomicznego w Katowicach, 166. Katowice: Uniwersytet Ekonomiczny w Katowicach. 


\section{Determinanty wzrostu wykorzystania wybranych źródeł energii odnawialnej w kontekście rozwoju zrównoważonego}

Streszczenie: Celem artykułu była identyfikacja czynników wpływających na wzrost wykorzystania odnawialnych źródeł energii (OZE) na obszarach wiejskich w kontekście rozwoju zrównoważonego. Badaniami objęto warunki ekonomiczne oraz rozpoznanie zmian w prawie odnoszące się do ustawy o odnawialnych źródłach energii z 2018 r., wynikające z polityki energetycznej Unii Europejskiej, zapewniającej korzystne warunki dla rozwoju OZE oraz wsparcie finansowe dla producentów energii ze źródeł odnawialnych. W niniejszym artykule skupiono się na czterech źródłach energii odnawialnej: biomasie drzewnej, biogazie, biodieslu i energii słonecznej, istotnych źródeł dla wiejskich gospodarstw rolnych i gospodarstw innych niż gospodarstwa rolne. Dyskusja przedstawia rolę wiejskich gospodarstw domowych w dostarczaniu i wykorzystywaniu OZE zgodnie z zasadą rozwoju zrównoważonego, opisuje korzystne nastawienie mieszkańców wsi do finansowania projektów w OZE ze środków publicznych oraz lokalny potencjał w tworzeniu miejsc pracy w sektorze OZE.

Słowa kluczowe: rozwój zrównoważony, energia odnawialna, subsydia, czynniki ekonomiczne, uwarunkowania prawne, zatrudnienie. 